\title{
Pengaruh Kualitas Layanan dan Produk terhadap Kepuasan serta Loyalitas Pelanggan KFC di Tangerang Selatan
}

\author{
Yesenia \\ Departemen Manajemen, Fakultas Ekonomi dan Manajemen \\ Institut Pertanian Bogor \\ Kampus Darmaga Bogor 16680 \\ Edward H Siregar \\ Departemen Manajemen, Fakultas Ekonomi dan Manajemen \\ Institut Pertanian Bogor \\ Kampus Darmaga Bogor 16880 \\ e-mail: edward.siregar@live.com
}

\begin{abstract}
PT. Fast Food Indonesia is the sole licensee of the leading fast food restaurants in the world, Kentucky Fried Chicken (KFC). The goal of the research is to analyze factors affecting customer satisfaction and loyalty to KFC. Research by Important Performance Analysis (IPA) and Customer Satisfaction Index (CSI) shows KFC customer satisfaction levels was $81.26 \%$, which indicates customers were very satisfied. Based on the results of the Partial Least Squares (PLS) analysis, it was found that service quality had no significant effect on satisfaction but showed significant effect on customer loyalty for customer total, student and non student models. Product quality had significant effects on satisfaction for all models. Furthermore, product quality had no significant effects on customer loyalty for customer total but had profound effects on loyalty for student and non student models. Finally, satisfaction had significant effects towards loyalty of all models.

Keywords: customer satisfaction index, kentucky fried chicken, important performance analysis, loyalty, satisfaction, partial least squares
\end{abstract}

\begin{abstract}
ABSTRAK
PT. Fast Food Indonesia adalah pemegang lisensi tunggal restoran cepat saji terkemuka di dunia yaitu Kentucky Fried Chicken (KFC). Tujuan penelitian ini adalah menganalisis atribut-atribut kualitas pelayanan dan produk yang dapat mempengaruhi kepuasan dan loyalitas pelanggan KFC. Hasil penelitian dengan Important Performance Analysis (IPA) dan Customer Satisfaction Index (CSI) menunjukan tingkat kepuasan pelanggan KFC sebesar $81.26 \%$ yang mengindikasikan pelanggan merasa sangat puas. Berdasarkan hasil analisis Partial Least Squares (PLS), Kualitas Layanan tidak berpengaruh signifikan terhadap kepuasan namun berpengaruh signifikan terhadap loyalitas pelanggan pada model total pengunjung, pelajar dan non pelajar. Kualitas produk berpengaruh signifikan terhadap kepuasan pada semua model. Kualitas produk tidak berpengaruh signifikan terhadap loyalitas pelanggan pada model total pengunjung namun kualitas produk berpengaruh signifikan terhadap loyalitas pada model pelajar dan non pelajar, serta kepuasan berpengaruh signifikan terhadap loyalitas pada seluruh model. Kata kunci: customer satisfaction index, kentucky fried chicken, important performance analysis, loyalty, satisfaction, partial least squares
\end{abstract}




\section{Pendahuluan}

Persaingan antar perusahaan pada masa kini bukan lagi berorientasi pada cara meningkatkan volume penjualan tetapi lebih berorientasi bagaimana memuaskan kebutuhan pelanggan dan menciptakan loyalitas. Pemasaran memiliki peranan yang penting dalam perusahaan untuk menciptakan nilai bagi pelanggan serta membangun hubungan yang kuat dengan pelanggan. Kepuasan pelanggan merupakan kunci dalam menciptakan loyalitas pelanggan (Kolter dan Armstrong 2008).

Semakin tingginya tingkat persaingan, akan menyebabkan pelanggan menghadapi lebih banyak pilihan alternatif untuk produk, harga, dan kualitas yang bervariasi, sehingga pelanggan akan selalu mencari nilai yang dianggap paling tinggi dari beberapa produk (Kotler 2005). Kualitas yang rendah akan menimbulkan ketidakpuasan pada pelanggan, tidak hanya pelanggan yang menikmati hidangan di restoran tersebut tapi juga berdampak pada orang lain. Pelanggan yang kecewa akan bercerita paling sedikit kepada 15 orang lainnya (Lupiyoadi dan Hamdani 2006). Untuk itu, upaya perbaikan kualitas layanan maupun kualitas produk akan jauh lebih efektif bagi keberlangsungan bisnis.

Seiring dengan kecepatan perkembangan era globalisasi dan kemajuan teknologi yang sangat pesat, pergerakan masyarakat terutama masyarakat urban menjadi sangat cepat. Kebutuhan masyarakat akan produk praktis pun semakin meningkat. Salah satu bisnis yang paling berkembang dalam penyedia produk praktis saat ini adalah restoran cepat saji (fastfood). Sebuah survei yang dilakukan oleh Roy Morgan Single Source terhadap 25 ribu responden berusia 14 tahun ke atas, menunjukkan bahwa selama kuartal 1/2009, sebanyak 54\% masyarakat Jakarta membeli makanan cepat saji. Sebanyak 53\% masyarakat Ibu Kota membeli makanan cepat saji dalam 6 bulan terakhir dan sebanyak $46 \%$ membeli dalam sebulan terakhir (Purnadi 2009). Data tersebut mengindikasikan bahwa terdapat peluang yang besar bagi pertumbuhan bisnis restoran siap saji. Kompetisi dalam industri restoran cepat saji menjadi semakin sengit dengan bermunculannya berbagai restoran sejenis.

Kota Tangerang Selatan adalah wilayah hasil pemekaran dari kabupaten Tangerang sejak tahun 2008. Daerah dengan jumlah penduduk lebih dari 1.2 juta jiwa ini memiliki tingkat populasi yang padat dan tingkat kesejahteraan masyarakat yang tinggi. Hal ini dapat dilihat dari Indeks Pembangunan Manusia (IPM) yang merupakan indeks yang digunakan sebagai alat ukur untuk melihat taraf hidup masyarakat meliputi tiga unsur yaitu usia hidup, pengetahuan dan standar hidup layak. IPM kota Tangerang Selatan pada tahun 2009 sebesar 74.82 dan merupakan yang tertinggi di Provinsi Banten serta termasuk kategori "menengah atas". Selain itu, pembentukan Produk Domestik Regional Bruto (PDRB) Tangerang Selatan dengan proporsi yang paling besar yaitu sektor perdagangan, hotel dan restoran sebesar $31.29 \%$ atau senilai 1.63 triliyun rupiah dan meningkat $30.96 \%$ dari tahun 2008. PDRB merupakan penjumlahan nilai output bersih perekonomian yang ditimbulkan oleh seluruh kegiatan ekonomi di suatu wilayah tertentu dan dalam satu kurun waktu tertentu (BPS 2009).

Peningkatan sektor perdagangan dan restoran, terutama disebabkan oleh semakin maraknya pusat-pusat perbelanjaan, bertambah jumlah restoran termasuk didalamnya restoran cepat saji. Jumlah restoran Kentucky Fried Chicken (KFC) di 
Tangerang Selatan hingga akhir tahun 2013 berjumlah 15 gerai yang tersebar dibeberapa kecamatan.

\begin{tabular}{lcc}
\multicolumn{2}{c}{ Tabel 1. Jumlah restoran dan store KFC } & berdasarkan kecamata \\
\hline Kecamatan & Jumlah Restoran & Jumlah KFC \\
\hline Serpong & 105 & 5 \\
Serpong Utara & 59 & 5 \\
Ciputat & 9 & 1 \\
Ciputat Timur & 10 & - \\
Pd Aren & 64 & 3 \\
Pamulang & 7 & 1 \\
Setu & 2 & - \\
\hline
\end{tabular}

Sumber : BPS Tangerang Selatan (2013)

Tangerang Selatan merupakan daerah yang subur bagi restoran cepat saji untuk tumbuh. Namun semakin banyaknya restoran cepat saji yang bermunculan, konsumen akan memiliki banyak alternatif pilihan dari pesaing-pesaing oleh karena itu perusahaan perlu memahami berbagai faktor yang dapat mempengaruhi kepuasan dan loyalitas konsumennya. KFC sebagai salah satu restoran cepat saji perlu terus megikuti perkembagan pasar (masyarakat) yang sedang berubah. Perubahan pasar, berupa perubaha gaya hidup yang semakin sering berpergian, sibuk, dan berorientasi keluarga, merupakan peluang sekaligus tantangan bagi KFC. KFC hendaknya berusaha agar selalu menyesuaikan diri dengan gaya hidup konsumen yang terus berubah.

Oleh karena itu, tujuan dari penelitian ini adalah sebagai berikut: 1) Menganalisis karakteristik konsumen KFC; 2) Menganalisis tingkat kepuasan pelanggan KFC; 3) Menganalisis apakah terdapat pengaruh kualitas pelayanan terhadap kepuasan dan loyalitas konsumen KFC berdasarkan data total pengunjung dan karakteristik profesi; 4) Menganalisis apakah terdapat pengaruh kualitas produk terhadap kepuasan dan loyalitas konsumen KFC berdasarkan data total pengunjung dan karakteristik profesi; 5) Menganalisis apakah terdapat pengaruh kepuasan terhadap loyalitas konsumen KFC

\section{Metode Penelitian}

Penelitian mengenai kepuasan dan loyalitas pelanggan KFC ini, pada mulanya didasarkan oleh persaingan bisnis restoran sejenis yang semakin ketat. Faktor pertama yang diperhatikan adalah tingkat kepentingan dan kinerja atribut yang digambarkan oleh analisis Importance Performance analysis (IPA) dan selanjutnya diukur tingkat kepuasan konsumen dengan analisis Customer Satisfaction Index (CSI). Setelah itu, dilakukan pengujian pengaruh kualitas layanan dan kualitas produk terhadap kepuasan dan loyalitas konsumen KFC dengan menggunakan analisis Structural Equation Modelling (SEM).

Penelitian dilakukan di KFC Alam Sutera yang berada di Kecamatan Serpong Utara dan KFC Bintaro Plaza yang berada di Kecamatan Pondok Aren. Kedua wilayah tersebut berada di wilayah Tangerang Selatan dengan jumlah rata-rata penduduk paling banyak sehingga sampel dapat lebih mewakili populasi. Penelitian ini berlangsung selama 3 bulan yaitu bulan Desember 2013 hingga Februari 2014 dan pengambilan sampel dilakukan pada akhir pekan. 
Pengumpulan data pada penelitian ini adalah data primer dan data sekunder yang bersifat kualitatif dan kuantitatif. Data primer merupakan data yang dikumpulkan dan di susun oleh peneliti di lapangan yang di dapat dari pembagian kuesioner dan wawancara dengan pihak pihak terkait. Data sekunder di dapat dari literatur-literatur, buku-buku, bahan pustaka lainnya yang terkait dalam penelitian ini.

Penelitian ini menggunakan metode survei, dengan teknik pengumpulan data wawancara langsung dengan pihak terkait. Populasi penelitian adalah pelanggan KFC Alam Sutera dan KFC Bintaro Plaza. Metode pemilihan contoh yang digunakan adalah metode non probability sampling dengan menggunakan convenience sampling. Penggunaan metode ini dilakukan dengan membagikan lembaran kuisioner pada pelanggan KFC yang ditemui di restoran ini. Tidak semua pengunjung rela di wawancarai untuk mengisi jawaban pada pertannyaan kuisioner, namun demikian jumlah responden yang rela mengisi kuisioner survei cukup banyak.

Jumlah sampel yang diambil dalam riset pemasaran dapat menggunakan rumus Slovin dengan tingkat signifikansi kesalahan $10 \%$. Data yang diperoleh dari manajer restoran KFC Bintaro Plaza, rata-rata jumlah pengunjung KFC Bintaro Plaza dan KFC Alam Sutera mencapai sekitar 44000 pengunjung setiap bulannya sehingga jumlah responden yang diambil dari data populasi berdasarkan rumus Slovin adalah 100 responden.

Pada penelitian ini terlebih dulu dilakukan pengujian kuesioner yang meliputi uji validitas dan realibilitas. Menurut Umar (2004), validitas adalah istilah yang dipakai untuk menyatakan sejauh mana data yang ditampung pada suatu kuesioner akan mengukur apa yang ingin diukur. Pengujian validitas dengan membagi kuesioner kepada 30 responden menunjukkan bahwa seluruh item valid karena memiliki nilai corrected Item Total Correlation lebih besar dari 0.361. Reliabilitas adalah istilah yang dipakai untuk menunjukan sejauh mana suatu hasil pengukuran relatif konsisten apabila alat ukur kita digunakan berulang kali (Umar 2004). Berdasarkan hasil uji realibilitas terhadap 30 responden dinyatakan bahwa kuisioner reliabel karena memiliki nilai alpha Cronbach 0.855 lebih besar dari 0.7 sehingga dianggap telah reliabel.

Variabel-variabel yang digunakan pada penelitian ini yaitu kualitas layanan, kualitas produk, kepuasan dan loyalitas. Adapun variabel kualitas layanan dan kualitas produk dapat di definisikan sebagai sesuatu yang bergantung pada kemampuannya untuk memuaskan kebutuhan pelanggan yang dinyatakan atau di implikasikan (Kotler dan Armstrong 2008). Dalam penelitian ini, kualitas mempunnyai dampak langsung pada kinerja produk atau jasa. Oleh karena itu, kualitas berhubungan erat dengan nilai kepuasan dan loyalitas pelanggan KFC. Masing-masing variabel memiliki indikatorindikator yang dapat menggambarkan variabel tersebut. Penjabaran lengkap indikator dapat dilihat di Tabel 2.

Tabel 2. Penjabaran atribut

\begin{tabular}{clc}
\hline Variabel & \multicolumn{1}{c}{ Indikator } & Kode \\
\hline Kualitas & Kebersihan fisik restoran & EA1 \\
Layanan & Kerapihan penampilan karyawan & EA2 \\
& Kemodernan sarana fisik yang dimiliki & EA3 \\
& Karyawan memberikan perhatian secara personal & EA4 \\
\hline
\end{tabular}


Lanjutan Tabel 2.

\begin{tabular}{|c|c|c|}
\hline Variabel & Indikator & Kode \\
\hline Kualitas & Pelanggan merasa mudah dalam menghubungi & EA5 \\
\hline \multirow[t]{9}{*}{ Layanan } & Karyawan bersungguh-sungguh dalam melayani & EA6 \\
\hline & Karyawan melayani dengan baik dari awal hingga akhir & EA7 \\
\hline & Karyawan menangani transaksi dengan akurat & EA8 \\
\hline & Karyawan memberikan pelayanan dengan cepat & EA9 \\
\hline & Karyawan membantu kesulitan pelanggan dengan cepat & EA10 \\
\hline & Karyawan menanggapi permintaan konsumen dengan cepat & EA11 \\
\hline & Restoran memiliki reputasi/citra yang baik & EA12 \\
\hline & Restoran memiliki karyawan yang kompeten dalam bidangnya & EA13 \\
\hline & Karyawan selalu ramah dalam memberikan layanan & EA14 \\
\hline Kualitas & Rasa produk yang enak & EA15 \\
\hline \multirow[t]{7}{*}{ Produk } & Variasi dan inovasi produk & EA16 \\
\hline & Kehigienisan produk & EA17 \\
\hline & Porsi yang pas & EA18 \\
\hline & Kemasan yang praktis dan menarik & EA19 \\
\hline & Jaminan halal & EA20 \\
\hline & Aroma yang enak & EA21 \\
\hline & Harga yang sesuai & EA22 \\
\hline Kepuasan & Berdasarkan pengalaman, pelanggan merasa senang makan di KFC & KL1 \\
\hline \multirow[t]{3}{*}{ Kosumen } & KFC telah memenuhi harapan pelanggan & KL2 \\
\hline & $\begin{array}{l}\text { Pelanggan percaya bahwa makan di KFC biasanya merupakan pengalaman } \\
\text { yang memuaskan }\end{array}$ & KL3 \\
\hline & $\begin{array}{l}\text { Secara keseluruhan, Anda percaya, KFC menyenangkan hati pelanggan } \\
\text { ketika makan di KFC. }\end{array}$ & KL4 \\
\hline Loyalitas & Pelanggan mengatakan hal positif tentang KFC & KL5 \\
\hline \multirow[t]{5}{*}{ Konsumen } & $\begin{array}{l}\text { Pelanggan memberikan rekomendasi kepada pihak lain untuk makan di } \\
\text { KFC. }\end{array}$ & KL6 \\
\hline & Kemungkinan besar, Anda akan makan di KFC lagi. & KL7 \\
\hline & Pelanggan jarang melakukan peralihan ke restoran cepat saji lainnya. & KL8 \\
\hline & $\begin{array}{l}\text { KFC merupakan pilihan pertama jika pelanggan ingin makan di restoran } \\
\text { cepat saji. }\end{array}$ & KL9 \\
\hline & Pelanggan percaya bahwa KFC merupakan restoran cepat saji terbaik & KL10 \\
\hline
\end{tabular}

Sumber: Data diolah (2014)

Pada analisi SEM dengan menggunakan SmartPLS akan dilakukan dua evaluasi model yaitu analisis evaluasi model pengukuran (Outer Model) dan analisis evaluasi model struktural (Inner Model). Evaluasi terhadap model pengukuran dikelompokan menjadi evaluasi terhadap model reflektif dan model formatif. Penelitian ini menggunakan dan menganalisis model reflektif. Evaluasi Outer model terlebih dahulu menganalisis 5 kriteria yaitu Loading factor, Composite realibility, Average Variance Extracted (AVE), akar kuadrat AVE, dan Cross Loading (Ghozali 2008).

Variabel laten dalam penelitian ini terdiri dari empat variabel, yaitu kualitas produk, kualitas layanan, kepuasan dan loyalitas. Setiap variabel laten masing-masing memiliki indikator reflektif yang mencerminkan variabel. Metode analisis digunakan untuk mengetahui secara kesuluruhan pengaruh positif langsung secara signifikan pada variabel laten eksogen yaitu kualitas produk dan kualitas layanan terhadap variabel laten endogen yaitu kepuasan dan loyalitas. 


\section{Hasil dan Pembahasan}

\section{III.1. Gambaran Umum PT. Fast Food Indonesia}

PT. Fast Food Indonesia didirikan pada tahun 1978 oleh Group Gelael, suatu perusahan keluarga yang menjalankan bisnis pasar swalayan di Indonesia. Setelah mendapat hak waralaba ekslusif dari KFC Corporation di Amerika Serikat untuk mengoperasikan restoran-restoran KFC di Indonesia. Pada bulan Maret 1979, Perseroan membuka restoran KFC pertama di jalan Melawai Raya 84-85 Kebayoran Baru, Jakarta Selatan. Keberhasilan Restoran KFC pertama ini segera di ikuti dengan pembukaan restoran-restoran KFC lainnya di Jakarta dan di kota-kota lainnya di Indonesia. Pada akhir tahun 1995, PT. Fast Food Indonesia mengoperasikan 129 Restoran KFC di 27 kota besar. Kini, pangsa pasar PT. Fast Food Indonesia telah memiliki lebih dari 450 Restoran yang tersebar luas di seluruh Indonesia.

\section{III.2. Karakteristik Umum Pelanggan}

Karakteristik pelanggan KFC Alam Sutera dan KFC Bintaro Plaza dalam penelitian ini sebanyak $61 \%$ perempuan dan $39 \%$ laki-laki. Usia dalam penelitian ini beragam namun didominasi oleh remaja dengan usia 16-25 tahun sebesar $61 \%$, selanjutnya oleh usia dibawah 15 tahun sebesar 17\%, 36-45 tahun 5\% dan 45 tahun keatas $4 \%$. Pendidikan Terakhir pelanggan terbanyak yaitu SMA sebesar 52\% dikarenakan mayoritas pelanggan berprofesi sebagai pelajar atau mahasiswa sebesar $58 \%$ dan Pegawai swasata sebesar 33\%. Top of Mind untuk restoran cepat saji memposisikan KFC sebagai retsoran cepat saji yang paling atas dipikiran pelanggan saat ingin datang ke restoran cepat saji sebesar $73 \%$, disusul pesaingnya yaitu MCDonald sebesar $18 \%$. Dalam sebulan terakhir rata-rata pelanggan berkunjung ke restoran cepat saji sebanyak 2-3 kali dengan prosentase 47\% dengan kunjungan ke KFC sebanyak 2-3 kali dengan prosentase $46 \%$. Rata-rata jumlah uang yang dihabiskan oleh pelanggan setiap kali berkunjung ke KFC adalah Rp 20 001-Rp 50000 sebesar 59\%.

\section{III.3. Important Performance Analysis (IPA)}

Berdasarkan hasil pengolahan data, atribut-atribut yang mempengaruhi kepuasan konsumen dapat dipetakan pada diagram Kartesius dengan sumbu $X$ mewakili tingkat kinerja dan sumbu $Y$ mewakili tingkat kepentingan.

1. Kuadran I

Kuadran ini menggambarkan daerah dengan tingkat kinerja di bawah harapan konsumen. Atribut-atribut yang termasuk kuadran satu atau prioritas untuk diperbaiki yaitu keramahan dalam pelayanan (A14), harga produk yang sesuai (A22) dan kesungguhan karyawan dalam melayani pelanggan (A6). Atribut-atribut yang berada pada kuadran ini hendaknya dijadikan prioritas utama bagi KFC untuk diperbaiki (dikurangi) karena konsumen merasa kurang puas pada atribut-atribut tersebut.

2. Kuadran II

Atribut-atribut yang termasuk kuadran dua yaitu kondisi ideal di mana tingkat kinerja yang tinggi mampu memenuhi tingkat harapan konsumen yang tinggi juga terhadap atribut tersebut. Atribut yang termasuk pada kuadran ini yaitu kebersihan fasilitas fisik restoran (A1), produk yang enak (A15), produk yang higienis (EA17), jaminan halal (A20), dan menangani transaksi dengan akurat (A8). Kelima atribut yang 
telah memenuhi ekspektasi konsumen yang tinggi hendaknya tetap dijaga dan dipertahankan prestasinya. Selain itu perludicari cara-cara baru dan inovasi baru (creat) sesuai dengan perubahan selera konsumen

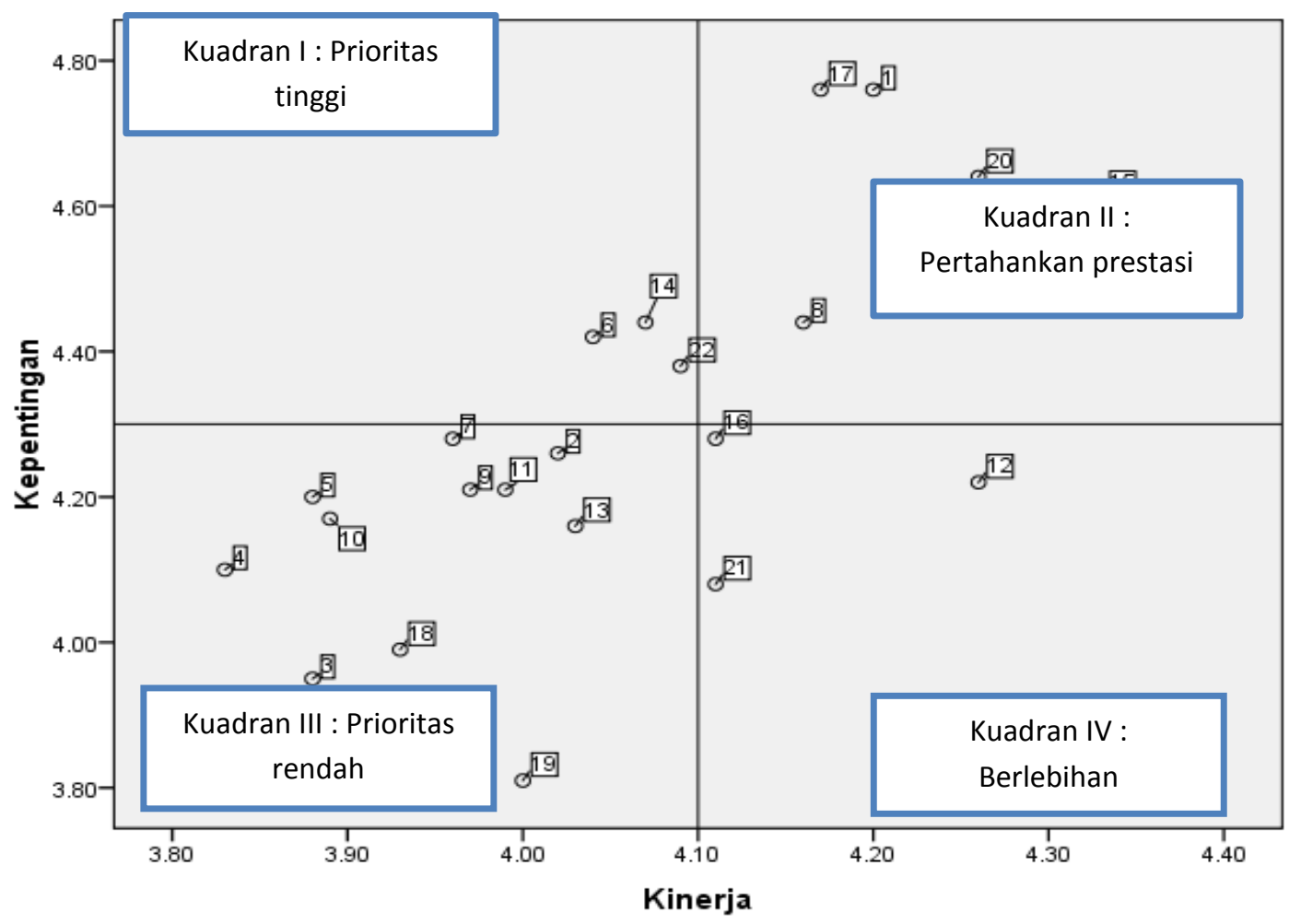

Gambar 1. Diagram kartesius IPA

\section{Kuadran III}

Atribut-atribut yang termasuk kuadran tiga atau prioritas rendah di mana tingkat kinerja yang rendah dan kurang penting bagi konsumen yaitu penampilan karyawan yang rapih dan santun (A2), sarana fisik yang mutakhir (A3), perhatian personal dari karyawan (A4), kemudahan dalam menghubungi pelayanan (A5), karyawan melayani dengan baik dari awal hingga akhir (A7), pelayanan yang cepat (A9), membantu kesulitan pelanggan dengan cepat (A10), menanggapi permintaan konsumen dengan cepat (A11), karyawan yang kompeten dalam bidangnya (A13), porsi yang pas (A18), kemasan yang praktis dan menarik (A19).

4. Kuadran IV

Atribut-atribut yang termasuk kuadran empat atau berlebihan dimana tingkat kinerja yang tinggi namun harapan yang rendah dari konsumen. Atribut yang termasuk dalam kuadran ini yaitu resputasi/citra (A12), aroma yang enak (A21), variasi dan inovasi produk (A16). Alokasi sumberdaya yang digunakan pada atribut-atribut di kuadran ini hendaknya dapat dikurangi dengan cara mengalokasikannya pada atribut yang berada pada prioritas utama untuk diperbaiki.

\section{III.4. Customer Satisfaction Index (CSI)}

Berdasarkan hasil perhitungan weighted factor dan weighted score, didapatkan nilai dari customer satisfaction index pelanggan KFC adalah sebesar $81.29 \%$. 
Berdasarkan nilai tersebut, maka dapat dikatakan bahwa pelanggan telah merasa sangat puas dengan kinerja KFC karena berada di dalam rentang 0.81-1.00 yang merupakan rentang yang menyatakan bahwa pelanggan telah merasa sangat puas.

Atribut kualitas layanan yang paling dipentingkan oleh pelanggan yaitu kebersihan fasilitas fisik restoran (A1), kesungguhan karyawan dalam melayani (A8), dan keramahan karyawan dalam pelayanan (A14). Kualitas Produk yang paling dipentingkan oleh pelanggan yaitu rasa produk yang enak (A15), kehigienisan produk (A17) serta jaminan halal produk (A20). Berdasarkan nilai weighted score atribut yang memberikan kontribusi dalam kepuasan pelanggan paling besar yaitu Kebersihan fasilitas fisik dan rasa produk.

Tabel 3. Perhitungan CSI

\begin{tabular}{ccccc}
\hline Atribut & Kepentingan & Evaluasi & WF & WS \\
\hline A1 & 4.49 & 4.20 & 0.047715 & 0.20040383 \\
A2 & 4.26 & 4.02 & 0.045271 & 0.18198937 \\
A3 & 3.95 & 3.88 & 0.043571 & 0.1690542 \\
A4 & 4.10 & 3.83 & 0.043571 & 0.16687566 \\
A5 & 4.20 & 3.88 & 0.044633 & 0.17317747 \\
A6 & 4.42 & 4.04 & 0.046971 & 0.18976408 \\
A7 & 4.28 & 3.96 & 0.045484 & 0.18011477 \\
A8 & 4.44 & 4.16 & 0.047184 & 0.1962848 \\
A9 & 4.21 & 3.97 & 0.04474 & 0.17761637 \\
A10 & 4.17 & 3.89 & 0.044315 & 0.17238363 \\
A11 & 4.21 & 3.99 & 0.04474 & 0.17851116 \\
A12 & 4.22 & 4.26 & 0.044846 & 0.19104357 \\
A13 & 4.16 & 4.03 & 0.044208 & 0.1781594 \\
A14 & 4.44 & 4.07 & 0.047184 & 0.19203826 \\
A15 & 4.61 & 4.33 & 0.04899 & 0.21212859 \\
A16 & 4.28 & 4.11 & 0.045484 & 0.1869373 \\
A17 & 4.76 & 4.17 & 0.050584 & 0.2109373 \\
A18 & 3.99 & 3.93 & 0.042402 & 0.16663868 \\
A19 & 3.81 & 4.00 & 0.040489 & 0.16195537 \\
A20 & 4.64 & 4.26 & 0.049309 & 0.21005739 \\
A21 & 4.08 & 4.11 & 0.043358 & 0.17820191 \\
A22 & 4.38 & 4.09 & 0.046546 & 0.19037407 \\
Total & & & 1.001594 & 4.06464718 \\
Rata-rata & & & 0.045527 & 0.18475669 \\
CSI (\%) & & & 81.2929437 \\
\hline S4 & & &
\end{tabular}

Sumber : Data diolah (2014)

\section{III.5. Analisis Partial Least Squares (PLS)}

Analisis dengan PLS digunakan untuk mengetahui hubungan antara variabelvariabel laten serta variabel laten dengan indikator konstruknya. Dalam penelitian ini, model PLS dibuat berdasarkan data total pengunjung dan data berdasarkan karakteristik profesi yaitu pelajar dan non pelajar. Pembuatan model PLS berdasarkan karakteristik pelajar dan non pelajar ini atas pertimbangan bahwa berdasarkan hasil penelitian pada karakteristik responden, pengunjung KFC didominasi oleh pelajar sebesar 58 orang dan sisanya 42 orang non pelajar. Untuk itu, pengujian model 
berdasarkan karakteristik ini perlu dilakukan karena dapat terlihat bahwa pengunjung KFC dapat dibagi menjadi dua kategori utama yaitu kategori pelajar dan non pelajar.

1. Analisis Model Pengukuran (Outer Model)

Pertama, dilakukan pendropan nilai loading factor yang kurang dari 0.7. Suatu Indikator dikatakan mempunyai realibilitas yang baik jika nilainya lebih besar dari 0.7 (Ghozali 2008). Setelah dilakukan pendropan loading factor dilihat apakah masih terdapat indikator yang loading faktornya dibawah 0.7. Jika masih terdapat loading faktor di bawah 0,7 maka dilakukan run ulang kembali, sampai hasil seluruh loading faktor untuk tiap indikator lebih besar dari 0.7.

\section{a. Outer Model Total Pengunjung}

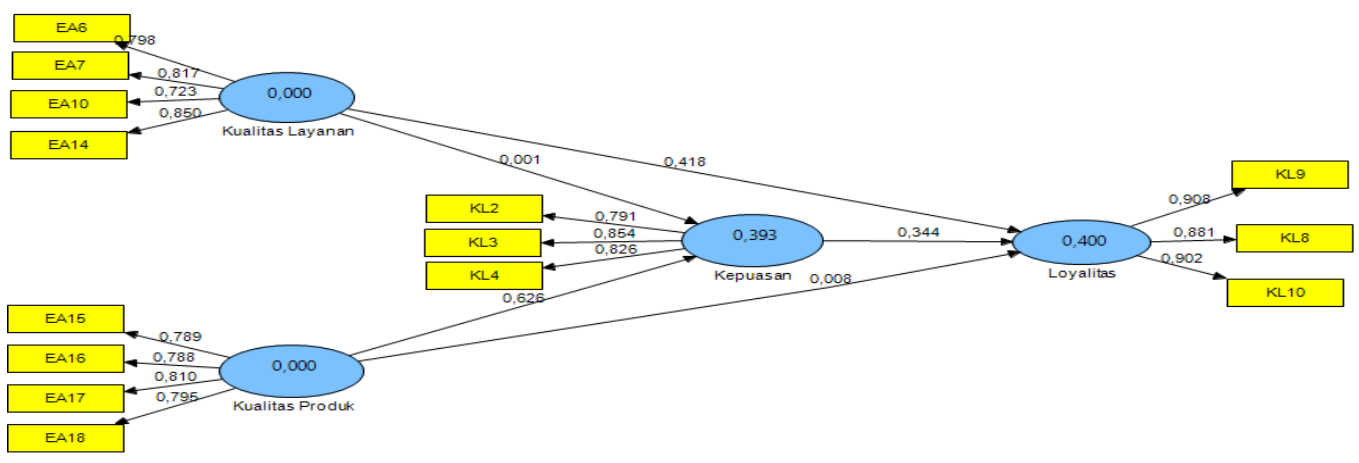

Gambar 2. Hasil outer model total pengunjung

Berdasarkan Gambar 2, variabel kualitas layanan dicerminkan oleh empat indikator utama yaitu karyawan bersungguh-sungguh dalam melayani (EA6), karyawan melayani dengan baik dari awal hingga akhir (EA7), karyawan membantu kesulitan pelanggan dengan cepat (EA10), dan karyawan selalu ramah dalam memberikan layanan (EA14). Dari keseluruhan variabel, variabel keramahan karyawan mencerminkan kualitas layanan dengan nilai paling besar yaitu 0.850 . Variabel kualitas produk dicerminkan oleh empat indikator utama yaitu rasa produk (EA15), variasi produk (EA16), kehigienisan produk (EA17) serta porsi produk (EA18). Di antara keseluruhan indikator, kehigienisan produk yang paling mencerminkan kualitas produk dengan nilai terbesar yaitu 0.810. Kepuasan pelanggan dapat dicerminkan oleh tiga indikator utama yaitu harapan yang terpenuhi (KL2), pengalaman yang memuaskan (KL3), kesenangan hati (KL4). Di antara ketiga indikator utama tersebut, pengalaman yang memuaskan bagi pelanggan mencerminkan kepuasan yang paling besar yaitu 0.819 . Variabel loyalitas dicerminkan oleh tiga variabel utama yaitu jarang melakukan peralihan ke restoran lain (KL8), menjadikan KFC sebagai pilihan pertama saat ingin makan di restoran cepat saji (KL9), dan kepercayaan bahwa KFC adalah restoran terbaik (KL10). Di antara berbagai indikator utama tersebut, indikator KFC sebagai pilihan pertama saat ingin makan di restoran cepat saji mencerminkan loyalitas pelanggan yang paling besar yaitu 0.908. Makna dari model total pengunjung hasil penelitian ini adalah bahwa KFC perlu secara berkesinambungan mempertahankan kualitas produk sajiannya dan meyakinkan pelanggan (potensial) yang sudah (akan) ada. Kondisi ini menciptakan peluang bagi KFC untuk melakukan penetrasi pasar. 
b. Outer Model Pelajar

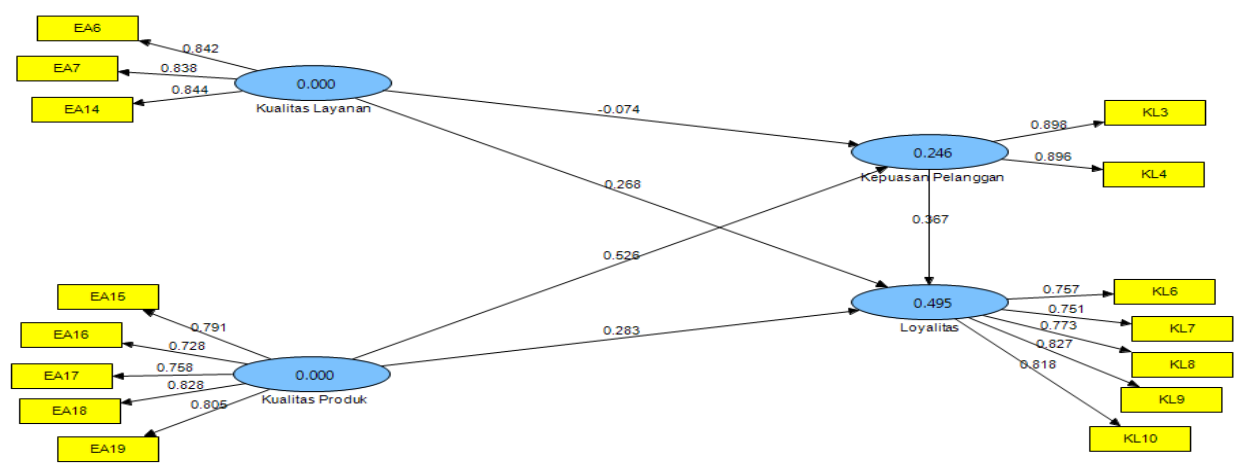

Gambar 3. Hasil outer model karakteristik pelajar

Berdasarkan Gambar 3, variabel kualitas layanan dicerminkan oleh tiga indikator utama yaitu karyawan bersungguh-sungguh dalam melayani (EA6), Karyawan melayani dengan baik dari awal hingga akhir (EA7), dan karyawan selalu ramah dalam memberikan layanan (EA14). Dari keseluruhan variabel, variabel keramahan karyawan mencerminkan kualitas layanan dengan nilai paling besar yaitu 0.844 . Variabel kualitas produk dicerminkan oleh lima indikator utama yaitu rasa produk (EA15), variasi produk (EA16), kehigienisan produk (EA17), porsi yang pas (EA18) serta kemasan yang praktis dan menarik (EA19). Di antara keseluruhan indikator, porsi yang pas paling mencerminkan kualitas produk dengan nilai terbesar 0.828. Kepuasan pelanggan dapat dicerminkan oleh dua indikator utama yaitu pengalaman yang memuaskan (KL3), kesenangan hati (KL4). Di antara ketiga indikator utama tersebut, pengalaman yang memuaskan bagi pelanggan mencerminkan kepuasan yang paling besar yaitu 0.898 .

Variabel loyalitas dicerminkan oleh lima variabel utama yaitu merekomendasikan KFC kepada pihak lain (KL6), Kemungkinan akan kembali ke KFC lagi (KL7), jarang melakukan peralihan ke restoran lain (KL8), menjadikan KFC sebagai pilihan pertama saat ingin makan di restoran cepat saji (KL9), dan kepercayaan bahwa KFC adalah restoran terbaik (KL10). Di antara berbagai indikator utama tersebut, indikator KFC sebagai pilihan pertama saat ingin makan di restoran cepat saji mencerminkan loyalitas pelanggan yang paling besar yaitu 0.827 . Pelajar adalah pelanggan (potensial) yang ekstra aktif secara umum dicirikan oleh keinginan akan kemudahan, keyamanan, dan suasana restoran yang "gaul" (artinya: restoran dilengkapi dengan musik dan internet), namun pelajar ini mudah juga bosan. Oleh karena itu, pihak KFC perlu mengembangkan produk dengan cara lebih banyak kergaman pilihan dan variasi menu. Harga produk KFC perlu disesuaikan dengan daya beli pelajar. Keputusan harga, produk baru dan pengembangan pasar di seluruh kota dan provinsi di tanah air perlu dilakukan denga keputusan yang logis dan sistematis oleh pihak pengelola (Saaty 1993) 


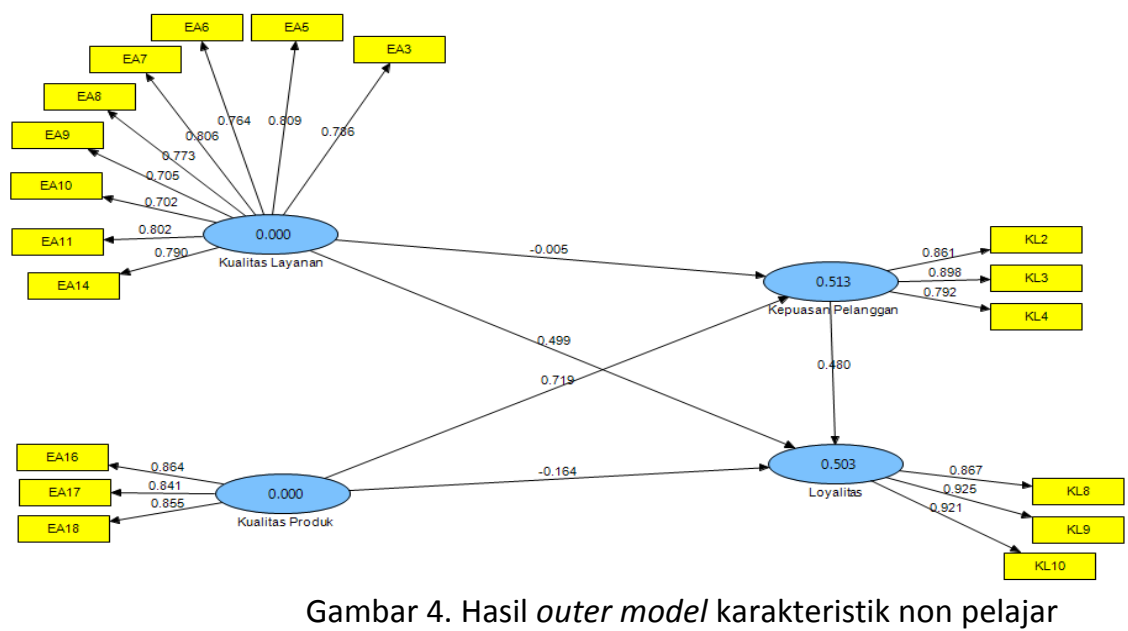

Berdasarkan Gambar 4, variabel kualitas layanan dicerminkan oleh delapan indikator utama yaitu kemuktahiran sarana fisik (EA3), kemudahan dalam menghubungi (EA5), karyawan bersungguh-sungguh dalam melayani (EA6), karyawan melayani dengan baik dari awal hingga akhir (EA7), menangani transaksi dengan akurat (EA8), karyawan membantu kesulitan pelanggan dengan cepat (EA10), menanggapi permintaan konsumen dengan cepat (EA11), serta karyawan selalu ramah dalam memberikan layanan (EA14). Dari keseluruhan variabel, kemudahan dalam menghubungi pelayanan mencerminkan kualitas layanan dengan nilai paling besar yaitu 0.809 .

Variabel kualitas produk dicerminkan oleh tiga indikator utama yaitu variasi produk (EA16), kehigienisan produk (EA17) serta porsi produk (EA18). Di antara keseluruhan indikator, variasi produk yang paling mencerminkan kualitas produk dengan nilai terbesar yaitu 0.864 . Kepuasan pelanggan dapat dicerminkan oleh tiga indikator utama yaitu harapan yang terpenuhi (KL2), pengalaman yang memuaskan (KL3), kesenangan hati (KL4). Di antara ketiga indikator utama tersebut, pengalaman yang memuaskan bagi pelanggan mencerminkan kepuasan yang paling besar yaitu 0.898. Variabel loyalitas dicerminkan oleh tiga variabel utama yaitu jarang melakukan peralihan ke restoran lain (KL8), menjadikan KFC sebagai pilihan pertama saat ingin makan di restoran cepat saji (KL9), dan kepercayaan bahwa KFC adalah restoran terbaik (KL10). Di antara berbagai indikator utama tersebut, indikator KFC sebagai pilihan pertama saat ingin makan di restoran cepat saji mencerminkan loyalitas pelanggan yang paling besar yaitu 0.925. Dari hasil penelitian ini KFC perlu secara berkesinambungan meciptakan beragam kreasi dalam produk dan layanannya seperti untuk keluarga yang memiliki anak dan remaja (kids and teens). Memberi ruang layanan untuk keluarga dalam pesta-pesta keluarga (misalnya hari ulang tahun) perlu di ciptakan.

Kedua, pengujian dari convergent validity adalah nilai Average Variance Extracted (AVE). Konstruk dapat memiliki nilai validity yang baik ketika nilai AVE lebih dari 0.5. Berdasarkan hasil analisis bahwa nilai AVE semua konstruk lebih besar dari 0.5 
194 |Yesenia, Siregar - Pengaruh Kualitas Layanan dan Produk

sehingga dapat disimpulkan bahwa semua konstruk memiliki tingkat validitas yang baik.

Tabel 4. Nilai average variance extracted

\begin{tabular}{lccc}
\hline & Total & Pelajar & Non Pelajar \\
\hline Kepuasan & 0.679580 & 0.804592 & 0.724859 \\
Kualitas Layanan & 0.637331 & 0.707429 & 0.595905 \\
Kualitas Produk & 0.632766 & 0.612854 & 0.728468 \\
Loyalitas & 0.804535 & 0.617763 & 0.818564 \\
\hline
\end{tabular}

Sumber : Data diolah (2014)

Selanjutnya pengukuran nilai realibilitas konstruk dengan melihat output smartPLS yaitu composite reliability lebih dari 0.7. Dari hasil output SmartPLS menunjukkan bahwa semua konstruk laten kualitas layanan, kualitas produk, kepuasan dan loyalitas memiliki nilai composite reliability lebih dari 0.7 , sehingga dapat disimpulkan bahwa semua konstruk memiliki tingkat reliabilitas dan validitas yang baik dengan standar yang telah dipenuhi.

Tabel 5. Composite reliability

\begin{tabular}{lccc}
\hline & Total & Pelajar & Non Pelajar \\
\hline Kepuasan & 0.864064 & 0.891716 & 0.808978 \\
Kualitas Layanan & 0.875087 & 0.878845 & 0.915307 \\
Kualitas Produk & 0.873280 & 0.887630 & 0.814398 \\
Loyalitas & 0.925071 & 0.889722 & 0.888737 \\
\hline
\end{tabular}

Sumber : Data diolah (2014)

Evaluasi selanjutnya adalah evaluasi diskriminan validity yang dilakukan dalam dua tahap yaitu melihat nilai cross loading dan membandingkan korelasi antar konstruk dengan akar AVE berupa hasil output SmartPLS variabel laten correlation.

a. Kriteria cross loading adalah setiap indikator yang mengukur konstruk/variabel laten sendiri berkolerasi lebih tinggi dibandingkan dengan konstruk/variabel laten lainnya. Hasil output cross loading menunjukkan nilai korelasi indikator lebih tinggi dengan korelasi konstruk masing-masing dibandingkan korelasi dengan konstruk lainnya. Sehingga dapat disimpulkan bahwa indikator pada konstruk kualitas produk, kualitas layanan, kepuasan dan loyalitas memiliki tingkat discriminant validity yang baik. Hal ini menunjukkan bahwa indikator tersebut memiliki tingkat validitas yang baik.

b. Membandingkan korelasi antar konstruk dengan akar AVE dengan kriteria bahwa nilai akar AVE harus lebih besar dari nilai korelasi maksimal konstruk. Perbandingan dilakukan dengan melihat akar AVE dengan korelasi tiap konstruk dibawahnya.

Berdasarkan hasil output SmartPLS, semua konstruk nilai akar AVE lebih besar dari nilai korelasi maksimal konstruk sehingga dapat dikatakan bahwa konstruk kualitas produk, kualitas pelayanan, kepuasan dan loyalitas memiliki tingkat discriminnat validity yang tinggi. Dengan demikian semua konstruk telah memenuhi convergent validity dan mempunyai discriminant validity yang tinggi sehingga dapat dilanjutkan untuk analisis inner model. 


\section{Analisis Evaluasi Model Struktural (Inner Model)}

Evaluasi model struktural menggambarkan hubungan antara konstruk/variabel laten eksogen dengan variabel laten endogen, apakah terdapat pengaruh positif atau negatif. Pengaruh antar konstruk dapat dilihat dari nilai R square seperti pada Tabel 6 .

Tabel 6. Nilai R square

\begin{tabular}{lccc}
\multicolumn{1}{c}{ Variabel Laten } & Total Pengunjung & Pelajar & Non Pelajar \\
\hline Kualitas Layanan & - & - & - \\
Kualitas Produk & - & - & - \\
Kepuasan Pelanggan & 0.392668 & 0.245785 & 0.512834 \\
Loyalitas & 0.399586 & 0.494553 & 0.503109 \\
\hline
\end{tabular}

Sumber : Data diolah (2014)

Berdasarkan hasil output SmartPLS overview untuk total pengunjung. Kualitas layanan dan kualitas produk mampu menjelaskan konstruk kepuasan pelanggan sebesar $39.27 \%$ dan sisanya $60.73 \%$ diterangkan oleh variabel lain yang tidak dirumuskan dalam model. Kualitas layanan, kualitas produk dan kepuasan pelanggan dapat menjelaskan konstruk loyalitas sebesar 39.96\% dan sisanya $60.04 \%$ diterangkan oleh variabel lain di luar model.

Berdasarkan karakteristik pelajar, kualitas layanan dan kualitas produk mampu menjelaskan konstruk kepuasan pelanggan sebesar $24.58 \%$ dan sisanya $75.42 \%$ diterangkan oleh variabel lain yang tidak dirumuskan dalam model. Kualitas layanan, kualitas produk dan kepuasan pelanggan dapat menjelaskan konstruk loyalitas sebesar 49.45\% dan sisanya $50.05 \%$ diterangkan oleh variabel lain di luar model.

Berdasarkan karakteristik non pelajar, kualitas layanan dan kualitas produk mampu menjelaskan konstruk kepuasan pelanggan sebesar $51.28 \%$ dan sisanya $48.72 \%$ diterangkan oleh variabel lain yang tidak dirumuskan dalam model. Kualitas layanan, kualitas produk dan kepuasan pelanggan dapat menjelaskan konstruk loyalitas sebesar $50.31 \%$ dan sisanya $49.69 \%$ diterangkan oleh variabel lain di luar model.

Evaluasi model struktural (inner model) selanjutnya yaitu melihat nilai estimasi koefisien jalur meliputi pengaruh positif langsung suatu konstruk laten dengan konstruk laten lainnya. Evaluasi ini melihat hasil output SmartPLS pada Path Corellation (Mean, Stdev, t-value) untuk melihat pengaruh langsung. Nilai t-statistik sebagai dasar dalam menilai pengaruh signifikan suatu konstruk dan melihat nilai Original Sample sebagai dasar dalam menilai seberapa besar pengaruhnya (Ghozali 2008).

Uji hipotesis dilakukan untuk menjawab persamaan penelitian. Pengujian hipotesis yang dilakukan, dapat dilihat dari nilai t-statistik. Batas untuk menolak atau menerima hipotesis yang diajukan adalah t-statistik 1.96 untuk $\mathrm{p}<0.05$ (two tailed). Berdasarkan Tabel 7, dapat diketahui pengaruh secara langsung antar konstruk.

Tabel 7. Path coefficient

\begin{tabular}{|c|c|c|c|c|c|c|}
\hline & \multicolumn{2}{|c|}{ Total Pengunjung } & \multicolumn{2}{|c|}{ Pelajar } & \multicolumn{2}{|c|}{ Non Pelajar } \\
\hline & $\begin{array}{l}\text { Original } \\
\text { Sample }\end{array}$ & $\begin{array}{c}\text { T- } \\
\text { Statistics }\end{array}$ & $\begin{array}{l}\text { Original } \\
\text { Sample }\end{array}$ & $\begin{array}{c}\mathbf{T}- \\
\text { Statistics }\end{array}$ & $\begin{array}{l}\text { Original } \\
\text { Sample }\end{array}$ & $\begin{array}{c}\text { T- } \\
\text { Statistics }\end{array}$ \\
\hline $\begin{array}{l}\text { Kepuasan Pelanggan } \\
->\text { Loyalitas }\end{array}$ & 0.343744 & 3.330310 & 0.366928 & 9.332043 & 0.480116 & 7.951769 \\
\hline
\end{tabular}


Lanjutan Tabel 7.

\begin{tabular}{lcccccc}
\hline & \multicolumn{2}{c}{ Total Pengunjung } & \multicolumn{2}{c}{ Pelajar } & \multicolumn{2}{c}{ Non Pelajar } \\
& $\begin{array}{l}\text { Original } \\
\text { Sample }\end{array}$ & $\begin{array}{c}\text { T- } \\
\text { Statistics }\end{array}$ & $\begin{array}{l}\text { Original } \\
\text { Sample }\end{array}$ & $\begin{array}{c}\text { T - } \\
\text { Statistics }\end{array}$ & $\begin{array}{c}\text { Original } \\
\text { Sample }\end{array}$ & $\begin{array}{c}\text { St- } \\
\text { Statistics }\end{array}$ \\
$\begin{array}{l}\text { Kualitas Layanan -> } \\
\text { Kepuasan }\end{array}$ & 0.001286 & 0.014423 & -0.073603 & 1.319122 & -0.00521 & 0.109661 \\
$\begin{array}{l}\text { Kualitas Layanan -> } \\
\text { Loyalitas } \\
\text { Kualitas Produk -> }\end{array}$ & 0.418271 & 3.372635 & 0.268465 & 5.649647 & 0.496780 & 8.526727 \\
$\begin{array}{l}\text { Kepuasan } \\
\text { Kualitas Produk -> }\end{array}$ & 0.625924 & 5.371275 & 0.525947 & 6.624689 & 0.719317 & 15.094262 \\
Loyalitas & 0.007951 & 0.059902 & 0.283436 & 4.796101 & 0.181720 & 3.005042 \\
\hline
\end{tabular}

Sumber : Data diolah (2014)

\section{a. Analisis Hasil Model Pengunjung Total}

Berdasarkan penjelasan di atas, dapat dianalisis bahwa pada model total pengunjung ternyata konstruk kepuasan dipengaruhi oleh kualitas produk dan loyalitas dipengaruhi oleh kualitas layanan. Kualitas Layanan berpengaruh positif terhadap kepuasan pelanggan namun pengaruhnya tidak signifikan karena nilai t-hitung $<\mathrm{t}$ tabel. Hal ini dapat disebabkan karena ada variabel lain yang lebih mempengaruhi kepuasan pelanggan seperti kualitas produk, harga, ataupun fasilitas restoran. Sementara itu kualitas layanan berpengaruh positif dan signifikan terhadap loyalitas dengan nilai t-hitung < t-tabel (1.96) yaitu sebesar 3.37. Hasil penelitian ini serupa dengan penelitian Amryyanti et al. (2010) yang menyebutkan bahwa semakin tinggi kualitas layanan maka akan semakin tinggi loyalitas pelanggannya. Qin dan Prybutok (2008) juga mengungkapkan ada pengaruh signifikan antara kualitas layanan terhadap loyalitas pelanggan restoran.

Kualitas Produk berpengaruh positif dan signifikan terhadap kepuasan pelanggan dengan nilai t-hitung $>$ t-tabel=1.96 yaitu sebesar 5.37. Hasil penelitian Haryanto (2013) juga menyebutkan bahwa kualitas produk berpengaruh secara signifikan terhadap kepuasan pelanggan restoran McDonald's Manado. Sebaliknya kualitas produk berpengaruh positif terhadap loyalitas namun tidak signifikan karena nilai thitung < t-tabel. Hal ini menunjukkan bahwa dalam membentuk loyalitas pelanggan diperlukan banyak variabel lain selain kualitas produk seperti kualitas layanan, harga, fasilitas dan faktor-faktor lainnya.

Kepuasan berpengaruh positif dan signifikan terhadap loyalitas pelanggan dengan nilai t-hitung 3.33. Hasil penelitian ini serupa dengan Aryani dan Rosinta (2010) bahwa kepuasan dan ketidakpuasan pelanggan akan memberikan dampak tersendiri pada perilaku pembelian selanjutnya.

b. Analisis Hasil Model Karakteristik Pelajar

Pada model karakteristik pelajar, konstruk kepuasan dipengaruhi oleh kualitas produk dan loyalitas dipengaruhi oleh kualitas layanan serta kualitas produk. Kualitas layanan mempengaruhi loyalitas dengan nilai t-hitung sebesar 5.65. Kualitas Produk berpengaruh positif dan signifikan terhadap kepuasan pelanggan dengan nilai t-hitung sebesar 6.62. Kualitas Produk juga berpengaruh signifikan terhadap loyalitas pelanggan 
dengan nilai t-hitung sebesar 4.79. Kepuasan berpengaruh positif dan signifikan terhadap loyalitas pelanggan dengan nilai t-hitung 9.33.

\section{c. Analisis Hasil Model Karakteristik Non Pelajar}

Pada model karakteristik pelajar, konstruk kepuasan dipengaruhi oleh kualitas produk dan loyalitas dipengaruhi oleh kualitas layanan serta kualitas produk. Kualitas layanan mempengaruhi loyalitas dengan nilai t-hitung sebesar 8.52. Kualitas Produk berpengaruh positif dan signifikan terhadap kepuasan pelanggan dengan nilai t-hitung sebesar 15.09. Kualitas Produk berpengaruh signifikan terhadap loyalitas pelanggan dengan nilai t-hitung sebesar 3.00. Kepuasan berpengaruh positif dan signifikan terhadap loyalitas pelanggan dengan nilai t-hitung 7.95.

\section{III.6. Implikasi Manajerial}

Kualitas layanan sangat penting dalam membentuk loyalitas pelanggan. Untuk meningkatkan kualitas pelayanannya, kualitas kinerja KFC dapat dilakukan dengan meningkatkan (raise), menghapuskan/menghilangkan (eliminate), mengurangi (reduce) dan menciptakan (create) dalam produk dan lain-lainnya (Kim dan Mauborgne 2005). KFC perlu meningkatkan keramahan dalam pelayanan. Variabel tersebut merupakan variabel yang paling dominan dalam mencerminkan kualitas pelayanan berdasarkan model total pengunjung dan pelajar. Namun, tentu saja variabel lain seperti kecepatan pelayanan, kesungguhan dalam pelayanan, penanganan transaksi yang akurat harus terus diperbaiki dan ditingkatkan kinerjanya. Selain itu, banyak responden KFC yang mengeluhkan lambatnya pelayanan saat kondisi ramai hingga harus berdiri lama untuk mengantri. Hal ini perlu di kurangi bahkan jika bisa perlu dihilangkan. Untuk itu, sebaiknya KFC membuka semua kasirnya saat kondisi ramai hingga tidak terjadi antrian yang panjang. Kemudian disediakan asisten yang membantu menyiapkan makanan atau minuman yang dipesan sehingga kasir tidak perlu menyiapkan pesanan sendiri dan dapat mempercepat proses transaksi.

Berdasarkan hasil penelitian kualitas produk berpengaruh secara positif terhadap kepuasan pelanggan namun tidak berpengaruh signifikan terhadap loyalitas pelanggan. Sebagai restoran cepat saji terkemuka di Indonesia maupun dunia, KFC terkenal dengan produk ayam gorengnya yang enak dengan bumbu rahasianya. Berdasarkan hasil penelitian ini, indikator yang paling dominan dalam mencerminkan kualitas produk yang dapat mempengaruhi kepuasan serta loyalitas konsumen adalah kehigienisan produk, porsi yang pas dan variasi produk. Untuk itu, selain meningkatkan cita rasa produk yang sesuai dengan keinginan konsumen KFC juga perlu menjamin kehigienisan produknya mulai dari makanan dan minumannya sampai wadah yang digunakan seperti piring, nampan, wadah minum, hingga sedotan. Untuk menghidari kejeuhan (kebosanan) pelanggan akan produknya, KFC perlu menciptakan rasa menu yang baru. Indikator kualitas produk lainnya seperti variasi produk, porsi yang pas, kemasan yang praktis, jaminan halal dan aroma yang enak juga perlu ditingkatkan guna meningkatkan kualitas produk agar dapat meningkatkan kepuasan dan loyalitas konsumen KFC.

Kebersihan restoran juga perlu diperhatikan dengan baik. Beberapa saran dari konsumen mengatakan sebaiknya piring kotor maupun sisa makanan dibersihkan dari 
meja walaupun konsumen belum meninggalkan meja. Hal ini agar konsumen menjadi lebih nyaman saat ingin beristirahat sejenak sebelum pergi atau sebelum memesan kembali. Sebagai restoran dengan jumlah pengunjung terbanyak anak muda, fasilitas wi-fi menjadi salah satu kebutuhan yang penting bagi konsumen. Namun, beberapa responden mengeluhkan wi-fi di KFC Alam Sutera maupun di KFC Bintaro Plaza terkadang tidak dapat digunakan dan suka dimatikan. Untuk itu, sebaiknya pihak KFC meningkatkan kinerja fasilitas wi-fi sehingga dapat membuat pelanggan merasa lebih betah berada di KFC sehingga dapat melakukan pemesanan kembali dan bahkan kembali datang ke KFC lebih sering lagi di waktu mendatang.

Selain dari segi peningkatan mutu layanan dan produk dari perspektif konsumen, KFC juga hendaknya menjaga mutu layanan dan produk dari perspektif perusahaan dengan sistem manajemen yang baik. Dari segi manajemen operasi ,KFC perlu menjaga mutu melalui quality assurance yang ketat untuk setiap bahan mentah, bahan setengah jadi hingga produk olahan yang telah siap saji. Pihak managemet perlu menerapkan kierja yang terpadu yang meliputi produk, proses, dan SDM-nya (Gaspersz dan Fontana 2011; Munandar et al. 2014). Dari segi SDM, penerapan SOP bagi karyawan dalam melayani lebih ditingkatkan implementasinya dan dapat diberikan reward kepada karyawan dengan kinerja yang tinggi. Selain itu, pihak manajemen juga dapat memberikan pelatihan-pelatihan secara berkala agar dihasilkan kinerja yang lebih optimal lagi.

\section{Kesimpulan}

Karakteristik konsumen KFC mayoritas berjenis kelamin perempuan. Konsumen yang datang terbanyak pada usia 16-25 tahun dan sebagian besar berpendidikan terakhir SMA serta berprofesi kebanyakan sebagai pelajar/mahasiswa. Tingkat pendapatan konsumen per bulan >Rp 1000000 dan setiap kali berkunjung, pelanggan KFC rata-rata menghabiskan Rp 20 000-RP 50 000. Berdasarkan hasil penelitian tingkat kepuasan pelanggan KFC sebesar $81.29 \%$ dan dalam kategori sangat puas berdasarkan perhitungan CSI.

Berdasarkan hasil penelitian, kualitas layanan tidak memiliki pengaruh terhadap kepuasan pelanggan namun memiliki pengaruh yang positif terhadap loyalitas pelanggan berdasarkan total pengunjung, karakteristik pelajar maupun non pelajar. Hal ini mengindikasikan bahwa semakin tinggi kualitas layanan maka konsumen akan semakin loyal terhadap KFC. Kualitas produk memiliki pengaruh positif terhadap kepuasan pelanggan berdasarkan total pengunjung, karakteristik pelajar maupun non pelajar. Kualitas produk tidak memiliki pengaruh signifikan terhadap loyalitas pelanggan berdasarkan total pengunjung namun berpengaruh signifikan berdasarkan karakteristik pelajar maupun non pelajar. Hal ini mengindikasikan bahwa semakin tinggi kualitas produk maka konsumen akan semakin puas. Kepuasan memiliki pengaruh positif terhadap loyalitas berdasarkan total pengunjung, karakteristik pelajar maupun non pelajar. Hal ini mengindikasikan bahwa semakin tinggi kepuasan maka konsumen akan semakin loyal terhadap KFC. 


\section{Daftar Pustaka}

Amryyanti R, Sukaatmadja IPG, Cahya KN. 2013. Pengaruh Kualitas Layanan, Produk, dan Kewajaran Harga Terhadap Kepuasan dan Loyalitas Pelanggan pada LnC Skin Care Singaraja. E-Jurnal Ekonomi dan Bisnis Universitas Udayana. [Internet]. [diunduh 2014 Jan 14]; 2(1): 22-29. Tersedia pada: http://ojs.unud.ac.id /index.php/EEB/article/view/4371.

Aryani D, Rosinta F. 2010. Pengaruh Kualitas Layanan terhadap Kepuasan Pelanggan dalam Membentuk Loyalitas Pelanggan. Jurnal Ilmu Administrasi dan Organisasi, Bisnis \& Birokrasi. [Internet]. [diunduh 2014 Jan 14]; 17(2): 114-126. Tersedia pada: http://journal.ui.ac.id/jbb/article/view/632.

[BPS] Badan Pusat Statistik Kota Tangerang Selatan. 2009. Proporsi (\%) Peranan Sektoral Terhadap Pembentukan PDRB Tangerang Selatan tahun 2009. Tangerang (ID): BPS.

[BPS] Badan Pusat Statistik Kota Tangerang Selatan. 2013. Statistik Restoran. Tangerang (ID): BPS.

Kim WC, Mauborgne R. 2005. Blue Ocean Strategy. Boston (US): Harvad Business School Press.

Gaspersz V, Fontana A. 20011. Malcolm Baldrige Criteria for Peformance Excellence. Bogor (ID): Vinchristo Publication.

Ghozali I. 2008. Structural Equation Modelling Metode Alternatif dengan Partial Least Square. Edisi 2. Semarang (ID) : Badan Penerbit Universitas Diponegoro.

Haryanto RA. 2013. Strategi Promosi, Kualitas Produk, Kualitas Layanan Terhadap Kepuasan Pelanggan Restoran McDonal's Manado. Jurnal EMBA. [Internet]. [diunduh 2014 Jan 14]; 1(4): 1465-1473. Tersedia pada: http://ejournal.unsrat. ac.id/index.php/emba/article/view/2923.

Kotler P. 2005. Manajemen Pemasaran. Jakarta (ID): Salemba Empat.

Kotler P, Armstrong G. 2008. Prinsip-Prisip Pemasaran, Jilid 1. Jakarta (ID): Erlangga.

Lupiyoadi R, Hamdani A. 2006. Manajemen Pemasaran Jasa. Jakarta (ID): Salemba Empat.

Munandar JM, Kartika L, Permanasari Y, Indrawan RD, Andrianto MS, Siregar E. 2014. Pengantar Manajemen Panduan Komprehensif Pengelolaan Organisasi. Bogor (ID): IPB Press.

Purnadi R. 2009. Cepat Saji Eksis di Ibukota. Majalah SWA. [Internet]. [diunduh 2013 Des 7]. Tersedia pada: http://www.swa.co.id.

Qin H, Prybutok VR. 2008. Determinants of Customer-Perceived Service Quality in FastFood Restaurants and their Relationship to Customer Satisfaction and Behavioral Intentions. Quality Management Journal, 15(2): 35-50.

Saaty TL. 1993. Pegambilan Keputusan Bagi Para Pimpinan. Jakarta (ID): PPM.

Umar H. 2004. Riset Pemasaran dan Perilaku Konsumen. Jakarta (ID): PT. Gramedia Pustaka Utama. 